\title{
TANGGUNG JAWAB KEJAHATAN PERBANKAN MELALUI MODUS OPERANDI SKIMMING
}

\author{
Victoria Linggoraharjo, Universitas Pelita Harapan Surabaya, \\ email: victoralingg@gmail.com
}

\begin{abstract}
Bank is a financial institution, which primary function includes collecting and granting deposits to the public based on fiduciary principle. The development of information technology has shifted financial products and services into electronic-based products and services, making money management easier than before. One of the electronic banking products, an ATM (Automatic Teller Machine) is operated by a financial institution, allowing customers to perform financial transactions. However, the information age shows that ATM skimming has become a rising threat. Skimming is a crime that occurs when skimmers install skimming devices on ATM machines in order to steal debit or credit card information. Skimming is done by surreptitiously installing a device at ATMs to record pin card data using magnetic strips. Therefore, the purpose of this study is to analyze which party is liable as a result of ATM skimming.

The result of this study shows that BCA is liable for the loss caused to its customers due to unauthorized withdrawals, considering Article 1367 of the Indonesia Civil Code states that a financial institution is responsible for the damage caused by matters which are under its supervision, that is, an ATM machine. Skimming is a criminal act in the banking sector that not only contravenes Banking Law, but also Criminal Law and Information and Electronic Transactions Law. Therefore, skimmer or fraudster is subject to Article 263 jo. Article 362 of the Criminal Code and/ or Article 30 (3) jo. Article 46 of the Information and Electronic Transactions Law.
\end{abstract}

Keywords: Skimming, ATM, Bank Fraud, Cybercrime.

\section{Pendahuluan}

Bank merupakan "suatu lembaga keuangan tempat penyimpanan dana atau uang dari perusahaan-perusahaan, baik badan usaha besar, menengah maupun kecil; baik perorangan maupun lembaga; pemerintah maupun swasta" (Arrasjid, 2011). Definisi bank secara normatif tertuang dalam Pasal 1 ayat (2) Undang-Undang Nomor 10 Tahun 1998 tentang Perubahan Atas Undang-Undang Nomor 7 Tahun 1992 tentang Perbankan (selanjutnya disebut sebagai UU Perbankan), yaitu "bank adalah badan usaha yang menghimpun dana dari masyarakat dalam bentuk simpanan dan menyalurkan kepada masyarakat dalam bentuk kredit dan/ atau bentuk-bentuk lainnya dalam rangka meningkatkan taraf hidup rakyat banyak". Sementara pengertian bank menurut A. Abdurrahman adalah "suatu jenis lembaga keuangan yang melaksanakan berbagai jasa, seperti memberikan pinjaman, mengedarkan mata uang, pengawasan terhadap mata uang, bertindak sebagai tempat penyimpanan benda-benda berharga, membiayai usaha perusahaan-perusahaan dan lain-lain" (Suyatno dkk, 2003). 
Pasal 1 ayat (2) UU Perbankan menjelaskan bahwa "Bank Umum adalah bank yang melaksanakan kegiatan usaha secara konvensional dan atau berdasarkan Prinsip Syariah yang dalam kegiatannya memberikan jasa dalam lalu lintas pembayaran". Dana simpanan bank menurut Pasal 1 ayat (5) UU Perbankan adalah "dana yang dipercayakan oleh masyarakat kepada bank berdasarkan perjanjian penyimpanan dana dalam bentuk giro, deposito, sertifikat deposito, tabungan dan atau bentuk lainnya yang dipersamakan dengan itu". Bentuk simpanan dana yang berbentuk giro menurut Pasal 1 ayat (6) UU Perbankan adalah "simpanan yang penarikannya dapat dilakukan setiap saat dengan menggunakan cek, bilyet giro, sarana perintah pembayaran lainnya, atau dengan pemindahbukuan". Sementara pengertian deposito sesuai Pasal 1 ayat (7) UU Perbankan adalah "simpanan yang penarikannya hanya dapat dilakukan pada waktu tertentu berdasarkan perjanjian Nasabah Penyimpan dengan bank". Selanjutnya pengertian tabungan menurut Pasal 1 ayat (9) UU Perbankan adalah "simpanan yang penarikanya hanya dapat dilakukan menurut Syarat tertentu yang disepakati, tetapi tidak dapat ditarik dengan cek, bilyet giro, dan atau alat lainnya yang dipersamakan dengan itu".

Fungsi utama perbankan Indonesia menurut Pasal 3 UU Perbankan adalah "sebagai penghimpun dan penyalur dana masyarakat". Trisadini P. Usanti dan Abd. Shomad berpendapat bahwa "fungsi perbankan menurut UU Perbankan merupakan fungsi bank sebagai lembaga intermediasi, yaitu bank sebagai penghimpun dan penyalur dana masyarakat (financial intermediary)" (Trisadini\&Shomad, 2017). Bank selain memiliki fungsi sebagai lembaga intermediasi, bank memiliki posisi sebagai agent of development atau agen pembangun, yang menurut Pasal 4 UU Perbankan adalah lembaga yang "bertujuan menunjang pelaksanaan pembangunan nasional dalam rangka meningkatkan pemerataan, pertumbuhan ekonomi, dan stabilitas nasional ke arah peningkatan kesejahteraan rakyat banyak" (Djuhhana, 2012). Di samping itu, bank juga merupakan agent of trust, yaitu sebagai "lembaga yang landasannya kepercayaan yang mewajibkan bank untuk menerapkan prinsip-prinsip perbankan dalam menyelenggarakan pelayanan atau jasajasa kepada perorangan baik kelompok/ perusahaan" (Suyatno dkk, Op.cit). Hal tersebut dipertegas dalam Pasal 2 UU Perbankan bahwa "Perbankan Indonesia dalam melakukan usahanya berasaskan demokrasi ekonomi dengan menggunakan prinsip kehati-hatian".

Berbicara mengenai pembinaan dan pengawasaan, Pasal 29 ayat (4) UU Perbankan menegaskan sebagai berikut: "Dalam memberikan kredit dan melakukan kegiatan usaha lainnya, bank wajib menempuh cara-cara yang tidak merugikan bank dan kepentingan nasabah yang mempercayakan dananya kepada bank". Dalam praktik perbankan, terdapat macam-macam kejahatan yang menimpa perbankan Indonesia, seperti pembobolan bank melalui letter of credit fiktif, pembobolan bank dan dana nasabah oleh pegawai karena penggelapan, penipuan atau kecurangan di bidang perkreditan, dan pencurian uang nasabah melalui ATM (skimming).

Skimming merupakan "tindakan pencurian data kartu ATM dengan cara menyalin (membaca dan menyimpan) informasi yang terdapat pada strip magnetic secara ilegal". Pengertian strip magnetic adalah garis lebar hitam yang terletak di bagian belakang kartu ATM. "Berfungsi seperti pita kaset, strip magnetic menyimpan data nomor kartu, masa berlaku dan nama masabah. Card skimming dilakukan dengan cara menempatkan alat pembaca kartu atau card skimmer pada slot kartu di mesin ATM" (www.ojk.go.id, 2019).

Di Indonesia semakin marak kejahatan skimming dan menurut laporan Edmiraldo Siregar dalam tulisannya "Indonesia Jadi Target Kejahatan Skimming", selama enam tahun berturut-turut sejak tahun 2011, kasus skimming di Indonesia terus meningkat dan pada 
tahun 2015, terjadi 1.549 kasus skimming atau dengan kata lain, $1 / 3$ kasus skimming di dunia terjadi di Indonesia (Siregar, www.liputan6.com, 2017). Posisi ini menempatkan Indonesia sebagai negara yang dominan menyumbang kasus skimming. Dari segi hukum perbankan Indonesia, kejahatan skimming merupakan salah satu tindak pidana yang ada hubungannya dengan kegiatan perbankan. Berdasarkan ketentuan pasal-pasal UU Perbankan di atas dikaitkan dengan kasus pembobolan ATM melalui modus operandi skimming, menarik bagi saya untuk membahas "Tanggung Jawab Kejahatan Perbankan Melalui Modus Operandi Skimming".

Berdasarkan hal tersebut, artikel ini berupaya untuk menjawab permasalahan siapakah yang bertanggung jawab atas ATM sebagai sarana transaksi perbankan dan pihak manakah yang bertanggungjawab atas hilangnya dana simpanan nasabah akibat adanya skimming.

\section{Pembahasan}

\subsection{Tanggung Jawab ATM Sebagai Sarana Perbankan}

Seiring berkembangnya teknologi informasi menimbulkan evolusi yang merubah strategis berbisnis bank mengarah kepada perbankan digital (digital banking). Layanan ini bertujuan untuk meningkatkan efisiensi atas kegiatan operasional perbankan dan mutu untuk lebih mengetahui dan memahami pelayanan bank terhadap nasabah. Yang dimaksud dengan layanan perbankan digital adalah kegiatan perbankan yang dilakukan menggunakan sarana elektronik yang dilakukan secara mandiri. Layanan perbankan yang berbasis teknologi informasi ini dikenal sebagai electronic banking (ebanking) (www.ojk.go.id, 2016).

E-banking memudahkan nasabah untuk memperoleh informasi, melakukan transaksi keuangan serta mendapatkan layanan perbankan yang dilakukan secara mandiri (Daniel, International Journal of Bank Marketing, 1999). E-banking memiliki berbagai delivery channel, diantaranya adalah Automatic Teller Machine (ATM) (www.ojk.go.id, Op.Cit.). Layanan tersebut memungkinkan nasabah "memperoleh informasi, melakukan komunikasi, registrasi, pembukaan rekening, transaksi perbankan, dan penutupan rekening, termasuk memperoleh informasi lain dan transaksi di luar produk perbankan, antara lain nasihat keuangan (financial advisory), investasi, transaksi sistem perdagangan berbasis elektronik (e-commerce), dan kebutuhan lainnya dari nasabah bank" (www.ojk.go.id, Op.Cit.).

Djumhana mengemukakan bahwa jasa perbankan adalah "refleksi dari kegiatan lembaga perbankan tersebut yang berupa: financial intermediary (lembaga perantara keuangan) sebagai bentuk kegiatan utamanya dan di bidang delivery system sebagai bentuk kegiatan di bidang administrasi dan layanan" (Djumhana, Op.Cit). Dengan kata lain, bank memiliki usaha pokok untuk menghimpun dan menyalurkan dana masyarakat serta memberikan jasa dalam lalu lintas pembayaran. Hal tersebut merupakan fungsi perbankan yang melekat dan tidak dapat dipisahkan. Oleh sebab itu, bank memiliki kewajiban untuk menjaga sarana yang digunakan dalam lalu lintas pembayaran dan melindungi dana nasabah yang dihimpun dalam sistem pembayaran.

Nasabah yang menggunakan produk bank, dalam hal ini adalah menggunakan jasa sistem pembayaran untuk transaksi keuangan, dikenal sebagai konsumen sebagaimana tertuang dalam Pasal 1 ayat (3) Peraturan Bank Indonesia Nomor 16/1/PBI/2014 tentang Perlindungan Konsumen Jasa Sistem Pembayaran (selanjutnya 
disebut sebagai PBI No. 16/1/PBI/2014) yang menentukan: "Konsumen Jasa Sistem Pembayaran yang selanjutnya disebut Konsumen adalah setiap pihak individu yang memanfaatkan jasa Sistem Pembayaran dari Penyelenggara untuk kepentingan diri sendiri dan tidak untuk diperdagangkan". Dalam hal ini, bank menawarkan produk-produk kepada konsumen (nasabah) sehingga konsumen dapat menghimpun dana melalui jasa sistem pembayaran bank.

Sebagaimana dikemukakan di atas, perkembangan teknologi informasi dan globalisasi telah menggeser layanan (produk) perbankan mengarah pada e-banking. Hal ini dikarenakan layanan e-banking memberikan kemudahan bagi nasabah untuk "melakukan transaksi keuangan secara nyaman dan efisien, misalnya transfer antar bank, pembayaran kartu pembayaran kartu kredit, pembayaran listrik, pembayaran telepon, pembayaran tagihan ponsel, pembayaran asuransi, pembayaran internet, pembayaran tiket penerbangan, dan virtual account" (www.ojk.go.id, Op.Cit.).

Pengertian e-banking tertuang dalam Pasal 1 ayat (3) Peraturan Bank Indonesia Nomor 9/15/PBI/2007 tentang Penerapan Manajemen Risiko Dalam Penggunaan Teknologi Informasi oleh Bank Umum (selanjutnya disebut sebagai PBI No. 9/15/PBI/2007) yakni:

(3) Layanan Perbankan Melalui Media Elektronik atau selanjutnya disebut Electronic Banking adalah layanan yang memungkinkan nasabah Bank untuk memperoleh informasi, melakukan komunikasi, dan melakukan transaksi perbankan melalui media elektronik antara lain ATM, phone banking, electronic fund transfer, internet banking, mobile phone.

Adapun salah satu layanan perbankan melalui e-banking adalah penggunaan fasilitas ATM (Automatic Teller Machine) atau Anjungan Tunai Mandiri. Definisi ATM menurut OJK merupakan "suatu terminal/mesin komputer yang terhubung dengan jaringan komunikasi bank, yang memungkinkan nasabah melakukan transaksi keuangan secara mandiri tanpa bantuan dari teller ataupun petugas bank lainnya" (www.ojk.go.id, Op.Cit.). Sementara menurut Suheimi, kartu ATM adalah "kartu plastik yang dapat digunakan oleh pemegangnya untuk membeli barang-barang dan jasa secara tunai maupun kredit dan bisa berguna sebagai penarikan uang secara tunai. Sedangkan ATM (Automated Teller Machine) adalah mesin/ komputer yang digunakan oleh bank untuk melayani transaksi keuangan seperti penyetoran uang, pengambilan uang tunai, pengecekan saldo, transfer uang dari satu rekening ke rekening lainnya, serta transaksi keuangan sejenis lainya secara elektronik" (Suheimi, 1995).

Jenis-jenis ATM dapat dibagi menjadi tiga, yaitu:

1. Mesin ATM yang hanya melayani transaksi non tunai.

2. Mesin ATM yang melayani transaksi penyetoran uang tunai Cash Deposit Machine atau CDM.

3. Mesin ATM yang dapat melayani semua transaksi yang telah disebutkan di atas (www.ojk.go.id, Op.Cit.).

Pengguna kartu ATM adalah "pemilik utama (nasabah) kartu ATM yang dapat melakukan transaksi keuangan melalui ATM, baik untuk penarikan uang secara tunai maupun pembelian/ pembayaran barang-barang dan jasa secara tunai maupun kredit" 
(Suheimi, Loc. Cit.). Untuk menggunakan ATM, pengguna "harus memiliki kartu ATM/ debit/kredit dan PIN. PIN adalah kode (4-6 digit) angka yang dibuat oleh nasabah saat pertama kali menerima kartu ATM di bank. Kode tersebut harus dijaga kerahasiaannya oleh nasabah supaya kartu ATM tidak dapat disalahgunakan oleh orang lain. Nasabah memasukkan kartu pada slot kartu di mesin ATM dengan memperhatikan sisi kartu yang harus dimasukkan terlebih dahulu, kemudian nasabah akan diminta untuk memasukkan PIN. Setelah itu nasabah dapat melakukan transaksi dengan memilih menu yang tertera pada layar monitor ATM." (Suheimi, Loc. Cit.).

Tujuan adanya fasilitas ATM adalah untuk "pemenuhan kebutuhan para nasabah yang bersifat konsumtif-pragmatis" (Prasetya, 2010). Adapun perjanjian yang timbul dari nasabah dan bank timbul dari penandatanganan formulir bahwa "calon nasabah pengguna fasilitas ATM tersebut menyetujui ketentuan-ketentuan yang telah ditentukan pihak bank tersebut" (Ibid.). Dengan adanya kesepakatan tersebut, nasabah dianggap telah memahami perjanjian penggunaan fasilitas yang berupa penyimpanan dana yang dibuat oleh pihak bank.

Menurut Ronny Prasetya, perjanjian penggunaan fasilitas ATM dapat dikategorikan sebagai "perjanjian yang tidak mempunyai nama dan jumlahnya tidak terbatas (unlimited)" (Ibid.). Pasal 1338 ayat (1) KUHPerdata menentukan bahwa "Semua perjanjian yang dibuat secara sah berlaku Undang-Undang yang mengatur bagi mereka yang membuatnya". Hal ini berarti perjanjian yang dibuat oleh pihak bank dengan nasabah merupakan produk bersama karena ketentuan perjanjian telah disepakati oleh kedua belah pihak yang akhirnya mengikat dan menjadi undang-undang bagi mereka yang mengadakan perjanjian. Namun dalam praktiknya, perjanjian penggunaan fasilitas ATM disediakan oleh pihak bank dengan syarat-syarat yang telah ditentukan sehingga menjadikan perjanjian tersebut bersifat sepihak. Dalam hal ini, tidak jarang pula timbul keluhan oleh pihak nasabah dengan ketentuan perjanjian yang telah disediakan oleh bank (Ronny Prasetya, Op.Cit). Meskipun tidak jarang timbul ketidakpuasan terhadap layanan yang diselenggarakan oleh bank, kejahatan di dunia maya semakin merak sehingga tidak ada rasa aman atau jaminan dalam penghimpunan dana di ATM. Dikatakan demikian karena sarana lalu lintas pembayaran, dalam hal ini adalah ATM, menjadi instrumen untuk disalahgunakan oleh pihak ketiga yang menimbulkan kerugian terhadap nasabah. Suheimi mengemukakan bahwa yang dimaksud dengan pihak ketiga adalah "hacker dan phreaker yaitu orang yang pekerjaannya memasuki atau mengakses secara tidak sah suatu sistem komputer maupun internet"( Suheimi, Op.Cit). Oleh karena itu, bank selaku penyelenggara sarana pembayaran wajib pula memberi perlindungan hukum bagi pemegang kartu ATM.

Perihal perlindungan hukum terhadap pengguna ATM, Pasal 1 ayat (2) PBI No. 16/1/PBI/2014 menjelaskan bahwa "Perlindungan Konsumen Jasa Sistem Pembayaran yang selanjutnya disebut Perlindungan Konsumen adalah segala upaya yang menjamin adanya kepastian hukum untuk memberi perlindungan kepada Konsumen Jasa Sistem Pembayaran." ATM merupakan salah satu jenis delivery channel atau sarana lalu lintas pembayaran yang memperoleh perlindungan hukum sebagaimana tertera dalam Pasal 2 PBI No.16/1/PBI/2014, yakni:

Perlindungan Konsumen yang diatur dalam Peraturan Bank Indonesia ini 
mencakup Perlindungan Konsumen dalam kegiatan jasa Sistem Pembayaran yang meliputi:

a. penerbitan instrumen pemindahan dana dan/atau penarikan dana;

b. kegiatan transfer dana;

c. kegiatan alat pembayaran dengan menggunakan kartu;

d. kegiatan uang elektronik;

e. kegiatan penyediaan dan/atau penyetoran uang Rupiah; dan

f. penyelenggaraan Sistem Pembayaran lainnya yang akan ditetapkan dalam ketentuan Bank Indonesia.

Dipertegas pada Pasal 3 PBI No.16/1/PBI/2014 bahwa perlindungan hukum terhadap nasabah yang menggunakan ATM dilandasi dengan prinsip-prinsip:
a. keadilan dan keandalan;
b. transparansi;
c. perlindungan data dan/atau informasi Konsumen; dan
d. penanganan dan penyelesaian pengaduan yang efektif.

Ditinjau dari penjelasan diatas, bank dalam menjalankan tugasnya sebagai penghimpun dan penyalur dana nasabah menggunakan berbagai cara, diantaranya adalah memanfaatkan sarana ATM. ATM adalah sarana milik bank yang harus dipantau oleh bank karena uang yang dikeluarkan atau diterima melalui ATM adalah uang bank. Hal ini sesuai dengan Pasal 1367 BW, yaitu "Seseorang tidak hanya bertanggung jawab atas kerugian yang disebabkan perbuatannya sendiri, melainkan juga atas kerugian yang disebabkan perbuatan-perbuatan orang-orang yang menjadi tanggungannya atau disebabkan barang-barang yang berada di bawah pengawasannya". Oleh karena itu, bank sebagai penyedia fasilitas ATM bertanggung jawab atas transaksi perbankan yang disebabkan oleh mesin ATM.

\subsection{Tanggung Jawab Tindak Pidana Skimming Atas Dana Nasabah}

Dalam perkembangan terakhir menunjukan semakin maraknya tindak pidana di dunia perbankan Indonesia yang dampaknya cukup besar di kalangan masyarakat, dunia perdagangan, serta hubungan kerja lintas negara. Permasalahan-permasalahan tersebut juga disebabkan karena "praktik-praktik kerusakan moral (moral hazard) dan mengabaikan prinsip-prinsip kehati-hatian" (Djumhana, Op.Cit).

Kejahatan di sektor perbankan tidak terlepas dari kejahatan ekonomi karena "kehidupan perbankan merupakan urat nadi kehidupan ekonomi" (Ibid). Conklin merumuskan unsur-unsur tindak pidana ekonomi sebagai berikut:

1. Suatu perbuatan melawan hukum yang diancam dengan sanksi pidana.

2. Yang dilakukan oleh seseorang atau korporasi di dalam pekerjaannya yang sah atau di dalam pencarian/ usahanya di bidang industri atau perdagangan.

3. Untuk tujuan: memperoleh uang atau kekayaan; menghindari pembayaran uang atau menghindari kehilangan/ kerugian kekayaan; memperoleh keuntungan bisnis atau keuntungan pribadi (Muladi\&Arief, 1992).

Tindak pidana perbankan melibatkan dana simpanan nasabah di bank sehingga perbuatan tersebut merugikan kepentingan berbagai pihak, diantaranya adalah bank 
selaku badan usaha, nasabah, sistem perbankan, otoritas perbankan, pemerintah serta masyarakat luas.

Ronny Prasetya mengemukakan bahwa "kejahatan dalam dunia maya (cyberspace) menghadirkan berbagai persoalan baru dan berat dengan skala internasional dan sangat kompleks dalam upaya pemberdayaan hukum agar bisa menanganinya. Kejahatankejahatan ekonomi termasuk kartu ATM dan pencurian uang merupakan masalah kedua yang sangat mengkhawatirkan bagi dunia perbankan, khususnya yang dilakukan di Asia" ( Ronny Prasetya, Op.Cit). Kejahatan di dunia ATM semakin marak dari waktu ke waktu, sehingga tidak ada lagi rasa aman atau jaminan untuk nasabah sebagai penghimpun dana di bank. ATM begitu mudah di bobol dan kartu ATM dengan mudah dipalsukan dengan berbagai macam cara, diantaranya adalah dengan modus operandi skimming. UU Perbankan sendiri mengatur tentang ketentuan pidana dan sanksi administratif yang diatur dalam Pasal 46 sampai dengan Pasal 50A UU Perbankan, namun tindak pidana tersebut umumnya menyangkut pihak internal bank sendiri. H.A.K. Moch. Anwar dalam bukunya Tindak Pidana di Bidang Perbankan memberikan dua pengertian terkait kejahatan perbankan. Pertama, "tindak pidana perbankan merupakan pelanggaran terhadap ketentuan dalam UU Perbankan dan kriminalisasinya tertuang dalam undang-undang itu sendiri" ( Djuhhana, Op.Cit, h. 511). Kedua, "tindak pidana di bidang perbankan memiliki pengertian yang lebih luas, yaitu segala jenis perbuatan melanggar hukum yang berhubungan dengan kegiatan-kegiatan bank, sehingga pelanggaran tersebut diancam dengan ketentuan pidana yang termuat di luar UU Perbankan, misalnya KUHP, UndangUndang Korupsi, Undang-Undang Tindak Pidana Pencucian Uang dan Undang-Undang Informasi dan Transaksi Elektronik"(www.ojk.go.id, 2019). Salah satu contoh tindak pidana di bidang perbankan adalah kejahatan perbankan berupa skimming.

Skimming merupakan salah satu jenis tindak pidana siber yang dikenal sebagai cyber theft atau identity theft. Pengertian skimming menurut Budi Suhariyanto adalah salah satu jenis tindak pidana siber yang dilakukan melalui jaringan komputer sistem, yang tidak mengenal perbatasan geografis, dengan memanfaatkan teknologi untuk mencuri data atau informasi pribadi nasabah yang terdapat pada magnetic stripe kartu ATM atau kartu kredit, sehingga pelaku tindak pidana memiliki akses terhadap rekening nasabah (Suhariyanto, 2013). Sementara menurut OJK, skimming merupakan "tindakan pencurian data kartu ATM dengan cara menyalin (membaca dan menyimpan) informasi yang terdapat pada strip magnetic secara ilegal"( OJK I, Op.Cit, h. 27.) Pengertian magnetic stripe pada kartu ATM atau kartu kredit adalah garis lebar hitam yang terletak pada bagian kartu ATM atau kartu kredit, dan berfungsi seperti pita kaset yang dapat menyimpan data (Adhi Maulana, www.liputan6.com, 2014).

Card skimming dilakukan dengan cara menempatkan alat pembaca kartu atau card skimmer pada slot kartu di mesin ATM (Ibid). Dalam skimming, pelaku berusaha mendapatkan data kartu dan PIN dengan dengan cara sebagai berikut:

1. Pelaku memasang alat skimmer pada mesin ATM;

2. Nasabah memasukkan kartu ke mesin ATM yang dipasangi alat skimmer, sehingga data kartu nasabah terbaca dan tersimpan pada alat tersebut;

3. Pelaku berusaha mendapatkan PIN ATM dengan cara mengintip tombol yang ditekan oleh nasabah atau dapat juga menggunakan kamera kecil yang dipasang oleh pelaku di mesin ATM; 
4. Pelaku membuat kartu palsu menggunakan data yang telah diperoleh dan bertransaksi menggunakannya PIN yang telah diketahui (terekam) (OJK I, Op.Cit, h. 28).

Suheimi mengemukakan bahwa skimming merupakan akibat dari penyalahgunaan oleh pihak ketiga. Yang dimaksud dengan pihak ketiga adalah "hacker dan phreaker, yaitu orang yang pekerjaannya memasuki atau mengakses secara tidak sah suatu sistem komputer maupun internet". Adapun cara-cara hacker mencuri data-data nasabah pemegang ATM adalah sebagai berikut:

1. Melalui komputer bank dan perusahaan kartu kredit;

2. Transhing, yaitu suatu cara dimana hacker membongkar/ memeriksa sampah perusahaan-perusahaan atau toko-toko yang diperkirakan menerima melalui kartu ATM (Suheimi, Op.Cit, h. 146).

Terkurasnya dana simpanan nasabah akibat kejahatan skimming menunjukan bahwa nasabah bank tidak mendapatkan perlindungan hukum secara penuh. Bank menggunakan uang nasabah, yang dalam hal ini menghimpun dana sebanyak-banyaknya dalam bentuk simpanan lalu mengelola dana tersebut untuk disalurkan kembali ke kreditur atau nasabah lainnya dalam bentuk pinjaman atau kredit. Nasabah dalam konteks UU Perbankan dapat dibagi menjadi dua, yakni nasabah penyimpan dan nasabah debitur. Berdasarkan Pasal 1 ayat 17 UU Perbankan, "Nasabah penyimpan adalah nasabah yang menempatkan dananya di bank dalam bentuk simpanan berdasarkan perjanjian bank dengan nasabah yang bersangkutan". Sementara menurut Pasal 1 ayat (18) UU Perbankan, "Nasabah debitur adalah nasabah yang memperoleh fasilitas kredit atau pembiayaan berdasarkan prinsip syariah atau yang dipersamakan dengan itu berdasarkan perjanjian bank dengan nasabah yang bersangkutan". Menurut Marhais Abdul Miru, "dalam praktik perbankan nasabah dibedakan menjadi tiga yaitu: Pertama, nasabah deposan yaitu nasabah yang menyimpan dananya pada suatu bank, misalnya dalam bentuk giro, tabungan dan deposito. Kedua, nasabah yang memanfaatkan fasilitas kredit atau pembiayaan perbankan misalnya kredit kepemilikan rumah. pembiayaan murabahah, dan sebagainya. Ketiga, nasabah yang melakukan transaksi dengan pihak lain melalui bank (walk in customer), misalnya transaksi antara importir sebagai pembeli dengan eksportir di luar negeri dengan menggunakan fasilitas letter of credit (L/C)" (Miru, 2004).

Ditinjau dari penjelasan di atas, adanya hubungan antara bank dan nasabah deposan yang terikat dalam suatu perikatan dimana bank bertanggung jawab atas dana simpanan nasabah. Hal ini dipertegas oleh Sutan Remy Sjahdeini tentang hubungan hukum antara bank dan nasabah, yakni:

Berdasarkan pada fungsi utama perbankan sebagai Lembaga intermediasi, yaitu berfungsi menghimpun dana masyarakat dan berfungsi menyalurkan dana masyarakat, maka terdapat dua hubungan antara bank dan nasabah, yaitu:

1) Hubungan hukum antara bank dan nasabah penyimpan dana.;

2) Hubungan hukum antara bank dan nasabah debitur.

Hubungan hukum yang sedemikian rupa ibaratnya membicarakan dua sisi sebuah mata uang logam; membicarakan satu sisi adalah tidak lengkap tanpa membicarakan sisi yang lain untuk dapat memahami dengan baik mata uang logam yang bersangkutan. Kedua sisi dapat dibedakan tetapi tidak dapat dipisahkan (Sjahdeini, 1994). 
Selanjutnya, Sutan Remy Sjahdeini mengemukakan bahwa "hubungan hukum antara bank dan nasabah penyimpan dalam praktik perbankan adalah konstruksi hubungan hukum atau perjanjian pinjam-meminjam khususnya perjanjian peminjaman uang dengan bunga sebagaimana pada Pasal 1754 BW. Hubungan antara bank dan nasabah penyimpan dana tidak tepat jika merupakan hubungan perjanjian penitipan sebagaimana pada Pasal 1694 BW atau perjanjian pemberian kuasa pada Pasal 1792 BW" (Ibid). Sementara Hermansyah berpendapat "hubungan hukum antara nasabah penyimpan dana bank didasarkan atas suatu perjanjian" (Hermansyah, Op.Cit, h. 144145). Oleh karena itu, sudah sepatutnya nasabah penyimpan dana memperoleh perlindungan hukum, yaitu perlindungan hukum yang diberikan oleh bank sebagai tanggung jawab utama bank yang dilandasi oleh kepercayaan. Hal tersebut dapat dilihat bahwa telah ada political will dari pemerintah untuk melindungi kepentingan nasabah penyimpan dana dengan UU Perlindungan Konsumen, selain yang diatur dalam UU Perbankan (Ibid).

ATM adalah sarana transaksi perbankan yang ada di bawah pengawasan bank sehingga bank bertanggung jawab atas segala akibat yang disebabkan oleh ATM sesuai ketentuan Pasal 1367 BW. Skimming adalah perbuatan pencurian data kartu ATM nasabah dengan cara menyalin informasi pada strip magnetic secara ilegal. Akibat perbuatan skimming adalah uang nasabah yang dipercayakan dalam bank dapat diambil secara melawan hukum. Dikatakan melawan hukum karena tanpa sepengetahuan dan persetujuan dari nasabah atau pemilik uang yang dipercayakan dalam bank. Skimming yang berakibat hilangnya atau berkurangnya uang nasabah di bank jelas merupakan tanggung jawab bank karena alat yang digunakan, yang dalam hal ini adalah mesin ATM, adalah sarana di bawah pengawasan dan kepemilikan bank. Pertanggungjawaban bank terhadap hilangnya dana simpanan nasabah ditinjau dari regulasi yang diterapkan oleh regulator jasa keuangan, yaitu pihak bank harus bertanggung jawab atas hilangnya dana simpanan nasabah dan kerugian yang menimpa nasabah. Hal ini tertuang dalam Pasal 19 ayat (1) UU Perlindungan Konsumen, yakni "Pelaku usaha bertanggung jawab memberikan ganti rugi atas kerusakan, pencemaran, dan/atau kerugian konsumen akibat mengkonsumsi barang dan/atau jasa yang dihasilkan atau diperdagangkan". Tanggung jawab bank atas hilangnya dana simpanan nasabah juga tertuang dalam Pasal 10 PBI No. 16/1/PBI/ 2014 yakni "Penyelenggara wajib bertanggung jawab kepada Konsumen atas kerugian yang timbul akibat kesalahan pengurus dan pegawai Penyelenggara." Dipertegas dalam Pasal 29 Peraturan Otoritas Jasa Keuangan Nomor 1/POJK.07/2013 tentang Perlindungan Konsumen Sektor Jasa Keuangan (selanjutnya disebut sebagai POJK No.1/POJK.07/2013), bahwa "Pelaku Usaha Jasa Keuangan wajib bertanggung jawab atas kerugian Konsumen yang timbul akibat kesalahan dan/atau kelalaian, pengurus, pegawai Pelaku Usaha Jasa Keuangan dan/atau pihak ketiga yang bekerja untuk kepentingan Pelaku Usaha Jasa Keuangan". Kecuali pelaku skimming ditemukan, yang dalam hal ini nasabah tetap meminta pertanggungjawaban atau pengembalian kerugian di bank karena berawalan dari perikatan nasabah dan bank yang mempercayakan uangnya untuk dikelola bank, baru pihak bank akan menindaklanjuti dengan pelaku skimming yang tertangkap.

Berbicara mengenai pertanggungjawaban pidana, hukum pidana mengenal asas legalitas (principle of legality), yang tertuang dalam Pasal 1 ayat (1) KUHP, yaitu setiap 
perbuatan pidana harus dirumuskan oleh suatu aturan undangan-undangan sebelum perbuatan seseorang dapat dipidana. Dikemukakan oleh Moeljatno bahwa asas dalam pertanggungjawaban pidana ialah: "Tidak dipidana jika tidak ada kesalahan (Geen strafzonder schukd; Actus non facit reum nisi mens sist rea)" (Moeljatno, 2008). Perlu diketahui bahwa perbuatan pidana harus dipisahkan dari pertanggungjawaban pidana dan kesalahan. Perbuatan pidana hanya menunjukan sifat larangannya saja, namun untuk menimbang apakah perbuatannya dapat dipidana atau dapat dipertanggungjawabkan harus melihat apakah ada kesalahan (guilt). Unsur-unsur kesalahan menurut Moeljatno adalah:

1. Melakukan perbuatan pidana (sifat melawan hukum).

2. Diatas umur tertentu mampu bertanggung jawab.

3. Mempunyai suatu bentuk kesalahan yang berupa kesengajaan atau kealpaan.

4. Tidak adanya alasan pemaaf (Ibid, h. 177).

Jadi, pertanggungjawaban pidana tidak semata-mata melakukan perbuatan pidana saja (actus reus), tetapi harus adanya niat (mens rea) untuk dapat dipidananya kejahatan. Skimming merupakan kejahatan yang dalam KUHP secara konvensional tindak pidana Pasal 263 KUHP dan Pasal 362 KUHP. Pengertian "membuat surat palsu" menurut Chainur Arrasjid adalah "membuat surat sedemikian rupa seakan-akan berasal dari sumber yang benar atau berhak untuk membuat surat tersebut sama sekali dari pihak yang tidak benar atau tidak berhak. Sedangkan pengertian "memalsukan surat" adalah "mengadakan perubahan dan isinya, sehingga sebab perubahan tersebut mengakibatkan materi atau substansi surat tersebut tidak sesuai lagi dengan isi yang sebenarnya atau dengan kata lain sudah tidak sesuai lagi dengan redaksi atau bunyi aslinya" (Arrasjid, 2018). Tindakan pelaku skimming yang dengan sengaja mendapatkan data nasabah secara melawan hukum yang kemudian mengkloning data yang diperoleh secara melawan hukum ke dalam kartu ATM yang kosong untuk melakukan aksi skimming merupakan perbuatan "membuat surat palsu". Perbuatan pelaku skimming yang menggunakan surat palsu sehingga mengakibatkan kerugian terhadap nasabah memenuhi unsur-unsur pidana sebagaimana tertuang dalam Pasal 263 KUHP.

Kemudian Pasal 362 KUHP tentang pencurian mengenal unsur subyektif dan unsur obyektif. Pasal 362 KUHP secara eksplisit merumuskan elemen "secara melawan hukum" yang "menunjuk kepada keadaan lahir atau obyektif yang menyertai perbuatan" (Moeljatno, Op. Cit, h. 68). Sifat melawan hukum yang dituju pada perbuatan atau objeknya adalah unsur melawan hukum yang obyektif. Di samping itu, Moeljatno berpendapat bahwa "ada kalanya sifat melawan hukumnya perbuatan tidak terletak pada keadaan objektif, tetapi pada keadaan subjektif, yaitu terletak dalam hati sanubari terdakwa sendiri" (Moeljatno, Op.Cit, h. 69). Misalnya dalam Pasal 362 KUHP yang dirumuskan sebagai pencurian, sifat melawan hukumnya perbuatan pencurian "tidak dinyatakan dari hal-hal lahir, tapi digantungkan pada niat orang yang mengambil barang tadi. Kalau niat hatinya itu baik, misalnya barang diambil untuk diberikan pada pemiliknya, maka perbuatan itu tidak dilarang, karena bukan pencurian. Sebaliknya kalau niat hatinya itu jelek, yaitu barang akan dimiliki sendiri dengan tak mengacuhkan kepada pemiliknya menurut hukum, maka hal itu dilarang dan masuk rumusan pencurian" (Ibid) 
Sifat melawan hukum yang tertuju kepada sikap batin terdakwa merupakan unsur melawan hukum yang subyektif. Niat pelaku skimming untuk memperoleh dan menguasai dana simpanan nasabah secara melawan hukum telah memenuhi unsur subyektif yang mensyaratkan adanya unsur "mens rea" untuk dapat dipidananya suatu perbuatan. Sementara perbuatan pelaku skimming yang mencuri dana simpanan nasabah bank yang seharusnya bukan miliknya telah memenuhi unsur objektif, yang dalam hal ini adalah perbuatan pidana atau actus rea.

Kejahatan skimming yang dilakukan melalui mesin ATM merupakan tindak pidana yang dilakukan melalui sistem elektronik, yang dalam hal ini dijerat Pasal 30 ayat (3) jo. Pasal 46 ayat (3) Undang-Undang Nomor 19 Tahun 2016 tentang Perubahan Atas Undang-Undang Nomor 11 Tahun 2008 tentang Informasi dan Transaksi Elektronik (selanjutnya disebut sebagai UU ITE) tentang illegal access, yang memiliki sanksi pidana penjara paling lama 8 tahun dan/ atau denda paling banyak Rp 800.000.000,- (delapan ratus juta rupiah). Illegal access merupakan tindakan awal untuk melakukan kejahatan skimming sehingga perbuatan pelaku skimming telah memenuhi unsur-unsur yang disyaratkan pada Pasal 30 ayat (3) UU ITE, yakni:

1. Dengan sengaja;

2. Tanpa hak atau melawan hukum;

3. Mengakses Komputer atau Sistem Elektronik;

Unsur dengan sengaja tampak dari sikap batin pelaku yang berniat untuk mencuri dana nasabah secara ilegal. Unsur tanpa hak atau melawan hukum tampak dari perbuatan sengaja pelaku skimming yang melanggar peraturan perundang-undangan atau tidak berdasarkan hukum. Unsur komputer atau sistem elektronik berkaitan dengan perangkat teknologi informasi dan komunikasi yang dipergunakan dalam kejahatan skimming, yaitu mengakses komputer atau sistem elektronik secara melawan hukum untuk mendapatkan data-data nasabah.

Uraian dan analisa dalam isu hukum ini menunjukkan bahwa bank sebagai penyedia fasilitas ATM bertanggung jawab atas kerugian yang disebabkan oleh mesin ATM, yang dalam hal ini adalah hilangnya dana simpanan nasabah akibat skimming, yang berupa pengembalian uang ke nasabah. Di samping itu, kejahatan skimming merupakan tindak pidana di bidang perbankan yang disamping melanggar ketentuan UU Perbankan, merupakan pelanggaran terhadap KUHP dan UU ITE. Apabila pelaku skimming tertangkap, pelaku dijerat pasal berlapis yakni Pasal 362 jo. Pasal 263 KUHP dan/ atau Pasal 30 ayat (3) jo, Pasal 46 ayat (3) UU ITE.

\section{Kesimpulan}

a. Bank menggunakan berbagai cara dalam melaksanakan tugas dan fungsinya, salah satunya adalah melalui sarana ATM dalam menghimpun dan menyalurkan dana masyarakat. Bank sebagai penyedia fasilitas berkewajiban untuk bertanggung jawab atas setiap transaksi yang dilaksanakan melalui sarana ATM karena ATM merupakan sarana yang ada di bawah pengawasan bank sesuai ketentuan Pasal 1367 KUHPerdata.

b. Pihak yang bertanggung jawab atas kejahatan skimming kartu ATM adalah pihak bank BCA. Dikatakan demikian karena ATM adalah salah satu sarana yang digunakan oleh bank dalam melayani dan menindaklanjuti penyaluran dan 
penerimaan dana dari nasabah debitur maupun kreditur. Kemudian berdasarkan hakikat perbankan menurut UU Perbankan sebagaimana diungkapkan di atas, dan mengingat Pasal 1367 KUHPerdata, dimana menyatakan tanggung jawab atas sarana maupun alat dalam hal ini adalah mesin ATM adalah tanggung jawab pemilik atas sarana atau alat tersebut (mesin ATM). Jadi yang bertanggung jawab atas berkurangnya dana nasabah melalui skimming dengan menggunakan mesin ATM adalah tanggung jawab penuh bank. Skimming merupakan tindak pidana di bidang perbankan sehingga pada pelaku dapat dijerat Pasal 263 jo. Pasal 362 KUHP dan/atau Pasal 30 ayat (3) jo. Pasal 46 UU ITE.

\section{Daftar Referensi}

Buku:

Chainur Arrasji. (2018). Hukum Pidana Perbankan. Jakarta: Sinar Grafika

Hermansyah. (2009). Hukum Perbankan Nasional Indonesia, Edisi Revisi. Jakarta: Kencana.

Hirsanudin. (2008). Hukum Perbankan Syariah di Indonesia Pembiayaan Bisnis dengan Prinsip Kemitraan. Yogyakarta: Genta Press.

Muhamad Djumhana. (2012). Hukum Perbankan di Indonesia. Bandung: PT. Citra Aditya Bakti.

Muladi, \& Barda Nawawi Arief. (1992). Bunga Rampai Hukum Pidana, Cetakan Pertama. Bandung: Alumni.

Moeljatno. (2008). Asas-Asas Hukum Pidana, Edisi Revisi, Jakarta: PT. Rineka Cipta:

Nindyo Pramono. (2006). Bunga Rampai Hukum Bisnis Aktual, Bandung: Citra Aditya Bakti.

Nindyo Pramono. (1999). "Mengenal Lembaga Perbankan di Indonesia sebuah Pendekatan dari Perspektif Hukum Ekonomi", dalam Penataran Hukum Perdata dan Ekonomi, Fakultas Hukum Universitas Gadjah Mada. Yogyakarta.

Peter Mahmud Marzuki. (2017). Penelitian Hukum, Jakarta: Kencana.

Ronny Prasetya. (2010). "Pembobolan ATM: Tinjauan Hukum Perlindungan Nasabah Korban Kejahatan Perbankan", Jakarta: Prestasi Pustaka.

Suheimi (1995). Kejahatan Komputer Ed.1. Jakarta: Andi Offset.

Thomas Suyatno, Djuhaepah T. Marala, Azhar Addullah, Johan Thoma Aponno, Tinon Yunianti Ananda, dan Chalik. 2003. Kelembagaan Perbankan. Jakarta: PT. Gramedia Pustaka Utama.

Prisadini P. Usanti \& Abd. Shomad. 2017. Hukum Perbankan. Jakarta: Prenada Media Group.

Trisniadi Prasastinah Usanti. 2013. Prinsip Kehati-hatian pada Transaksi Perbankan, Surabaya: Airlangga University Press.

\section{Surat Kabar}

Bank Indonesia, “Gerai Info”, Newsletter Bank Indonesia, Edisi XIV, Mei 2011.

Edmiraldo Siregar, Indonesia Jadi Target Kejahatan Skimming", Liputan6

(online), 26 September 2017, h.1,

https:// www.liputan6.com/news/read/3108225/indonesia-jadi-targetkejahatan-skimming, diakses pada tanggal 26 April 2019.

Lis Yuliawati, "Polisi Belum Temukan Aliran Dana Skimming RP ke Parpol", MSN (online) ,21 Maret 2019, https://www.msn.com/id$\mathrm{id} /$ berita/nasional/polisi-belum-temukan-aliran-dana-skimming-rp-keparpol/ar-BBV2aE8, diakses pada tanggal 29 Juli 2019.

Merdeka, “ATM Dibobol, Bank BCA Rugi Rp 300 juta”, Merdeka (online), 18 
Maret 2019, https://www.merdeka.com/uang/atm-dibobol-bank-bca-rugi-rp300-juta.html, diakses pada tanggal 29 Juli 2019.

Nur Habibie, "Ramyadjie Priambodo Dapat Data Nasabah dari Komunitas

Black Market', Merdeka (online), 20 Maret 2019,

https:// www.merdeka.com/peristiwa/ramyadjie-priambodo-dapat-datanasabah-dari-komunitas-black-market.html, diakses pada tanggal 29 Juli 2019.

Nur Habibie, "Kasus Pembobolan ATM Ramyadjie Priyambodo, Polisi Periksa 10 Saksi", Merdeka (online), 19 Maret 2019, https:// www.merdeka.com/peristiwa/kasus-pembobolan-atm-ramyadjiepriyambodo-polisi-periksa-10-saksi.html, diakses pada tanggal 29 Juli 2019

Rindi Nuris Belarosdela, "Kronologi Penangkapan Pria yang Disebut Kerabat Prabowo Terkait Pembobolan ATM", Kompas (online), 18 Maret 2019, https://megapolitan.kompas.com/read/2019/03/18/15565401/kronologipenangkapan-pria-yang-disebut-kerabat-prabowo-terkait, diakses pada tanggal 11 Juni 2019.

Rindi Nuris Velarosdela, "Berkas Perkara Kasus Skimming ATM Lengkap, Tersangka Ramyadjie Siap Disidang", Kompas (online), 24 April 2019, https://megapolitan.kompas.com/read/2019/04/24/15095651/berkas-perkarakasus-skimming-atm-lengkap-tersangka-ramyadjie-siap, diakses pada tanggal 29 Juli 2019.

Tribunenews, “5 Fakta Kasus Ramyadjie Priaambodo Pembobol ATM yang Raup Keuntungan Hingga Ratusan Juta", Tribunenews (online), 20 Maret 2019, https://www.tribunnews.com/section/2019/03/20/5-fakta-kasusramyadjie-priambodo-pembobol-atm-yang-raup-keuntungan-hingga-ratusan-

Artikel juta, diakses pada tanggal 29 Juli 2019.

Hermawan, Pengertian Enkripsi Beserta Cara Kerja dan Jenis-Jenis Enkripsi
(Pembahasan
Lengkap),
$16 \quad$ Mei

https://www.nesabamedia.com/pengertian-enkripsi/, diakses pada tanggal 29 Juli 2010.

OJK, Pahami \& Hindari: Buku Memahami dan Menghindari Tindak Pidana
Perbankan,
https:// www.ojk.go.id/id/berita-dan-

kegiatan/publikasi/Documents/Pages/Buku-Pahami-dan-Hindari-Tindak-

Pidana-Perbankan/BUKU\%20PAHAMI\%20DAN\%20HINDARI\%20-

\%20MEMAHAMI\%20DAN\%20MENGHINDARI\%20TINDAK\%20PIDANA \%20

\%20PERBANKAN.pdf, h.7-8, diakses pada tanggal 23 April 2019.

OJK , Bijak Ber-eBanking,

https:// www.ojk.go.id/Files/box/buku\%20bijak\%20ber-ebanking.pdf,

Mei 2015, diakses pada tanggal 19 April 2019.

OJK, Panduan Penyelenggara Digital Branch oleh Bank Umum,

https://www.ojk.go.id/id/kanal/perbankan/Documents/Pages/Forms/AllIte ms/Panduan_Penyelenggaraan_Digital_Branch_DPNP_FINAL\%20(FIX).pdf,

Desember 2016, diakses pada tanggal 19 April 2019. 